\title{
PENGARUH KEPERCAYAAN, KEAMANAN DAN KUALITAS PRODUK TERHADAP KEPUTUSAN PEMBELIAN
}

\author{
Mutiara 1) \\ 1) Mahasiswa Program Manajemen Studi Strata Satu FE UnKris \\ Email : mutiaraariani97@gmail.com \\ Imam Wibowo 2 ) \\ 2) Dosen Program Studi Manajemen FE UnKris \\ Email : wibowoimam253@gmail.com
}

\begin{abstract}
This research analyzes ecommerce on online purchasing decisions. The purpose of this study was to determine the influence of trust, safety, product quality on online purchasing decisions at shopee. The total population used was 1,200 taken from researchers' instagram followers and the number of samples used in this study were 92 respondents. This research is a quantitative study, using simple linear regression analysis and multiple linear regression. The results of this study were obtained simultaneously showing the positive influence of product safety and quality while trust has a negative influence on purchasing decisions. Partially, there is a positive and significant influence of trust, safety and product quality on purchasing decisions. And there is advice given, that shopee companies need to pay attention to consumer confidence and develop the quality of products that are needed and desired by consumers in shopping online.
\end{abstract}

Keyword : Trust, safety, product quality, purchasing decisions.

\section{PENDAHULUAN}

Teknologi komunikasi, media dan informasi telah membawa pengaruh cara dan pola transaksi bisnis di industri perdagangan. Salah satu kemajuan teknologi yang banyak digunakan oleh orang, organisasi, maupun perusahaan adalah internet. Hal ini memberikan kesempatan bagi para pelaku usaha khususnya perdagangan dengan menyediakan atau membuat toko online sebagai bagian dari e-commerce.

Pengertian E-Commerce atau sering disebut perdagangan elektronik menurut Jony Wong (2010) adalah pembelian, penjualan dan pemasaran barang serta jasa melalui sistem elektronik. Seperti televisi, radio dan jaringan komputer atau internet. E-Commerce juga dapat diartikan sebagai suatu proses berbisnis dengan menggunakan teknologi elektronik yang menghubungkan antara perusahaan, konsumen dan masyarakat dalam bentuk transaksi elektronik dan pertukaran atau penjualan barang, servis, dan informasi secara elektronik. Menurut Triana (2015) E-commerce sebagai "bentuk transaksi perdagangan atau perniagaan dengan menggunakan media elektronik". Sedangkan menurut Lupiyoadi (2013) bisnis elektronik dalam pengertian bisnis internet adalah "bagaimana memanfaatkan internet untuk membangun hubungan lebih dekat dengan konsumen dan mitra bisnis".

Salah satu jenis e-commerce yang saat ini berkembang pesat di Indonesia adalah e-commerce jenis marketplace. Marketplace yaitu sebuah website atau aplikasi online yang memfasilitasi proses jual beli dari berbagai toko. Indonesia adalah salah satu negara yang trend dengan toko online atau online shop. Salah satu online shop yang cukup populer di Indonesia adalah Shopee. Terdapat 
beberapa manfaat e-commerce seperti konsumen dapat berbelanja atau melakukan transaksi selama 24 jam, konsumen juga bisa melakukan pembelian setiap waktu bahkan konsumen juga dapat memilih sendiri produk yang diinginkan.

Kemudahan dalam bertransaksi secara online mempengaruhi konsumen dalam melakukan keputusan pembelian. Keputusan pembelian merupakan salah satu tahapan dalam proses sebelum perilaku pembelian. Pada proses tahapan keputusan pembelian sebelumnya, konsumen sudah dihadapkan pada beberapa pilihan alternatif sehingga pada tahap ini konsumen akan memutuskan untuk membeli produk disitus pilihannya. Adapun Keputusan Pembelian Online (Online Purchase) menurut Andrade (2000) adalah "proses seleksi yang mengkombinasikan pengetahuan untuk mengevaluasi dua atau lebih perilaku alternatif dan memilih salah satu diantaranya yang kuat hubungannya dengan karakter personal, vendor/service, website quality, sikap pada saat pembelian, maksud untuk membeli online dan pengambilan keputusan"

Banyak faktor yang mempengaruhi keputusan pembelian secara online, diantaranya adalah kepercayaan, keamanan, kualitas produk, persepsi konsumen dan kualitas layanan. Shopee sebagai online shop yang sudah dikenal luas, menerapkan lingkungan belanja yang aman seperti cek penilaian toko dari pembeli sebelumnya untuk menjamin berbelanja dari toko terpercaya. Keamanan dari segi transaksi bisa dilakukan dengan cara bayar di tempat, transfer bank, kartu kredit dan metode lainnya.

Kepercayaan sebagaimana pendapat Kotler dan Keller (2016), adalah "kesediaan perusahaan untuk bergantung pada mitra bisnis. Itu tergantung pada sejumlah faktor interpersonal antar organisasi, seperti kompetensi yang dirasakan perusahaan, integritas, kejujuran,dan kebijakan”. Adapun menurut McKnight (2015), menyatakan sebagai berikut: "kepercayaan pelanggan sebagai harapan positif konsumen terhadap produsen atas kemampuannya menghasilkan produk yang memuaskan pelanggan".

Faktor lainnya yang mempengaruhi keputusan pembelian adalah keamanan dalam pembelian secara online. Masalah keamanan merupakan salah satu aspek penting dari sebuah sistem informasi. Keamanan transaksi online adalah bagaimana dapat mencegah penipuan (cheating) atau paling tidak mendeteksi adanya penipuan disebuah sistem yang berbasis informasi, dimana informasinya sendiri tidak memiliki arti fisik. Park \& Kim (2006) medefinisikan keamanan atau security sebagai "kemampuan toko online dalam melakukan pengontrolan dan penjagaan keamanan atas transaksi data". Lebih lanjut Park dan Kim mengatakan bahwa jaminan keamanan berperan penting dalam pembentukan kepercayaan dengan mengurangi perhatian konsumen tentang penyalah gunaan data pribadi dan transaksi data yang mudah rusak.

Faktor lainnya yang dapat mempengaruhi keputusan pembelian adalah kualitas produk. Seorang konsumen membeli suatu produk salah satunya dari segi kualitas produk yang ditawarkan. Kualitas produk merupakan salah satu kunci keberhasilan dalam persaingan diantara para pelaku usaha.. Kotler dan Keller (2016), menyatakan bahwa kualitas produk adalah" kemampuan suatu barang untuk memberikan hasil atau kinerja yang sesuai bahkan melebihi dari apa yang diinginkan pelanggan".

Banyak penelitian yang dilakukan untuk mengetahui pengaruh kepercayaan, keamanan, kualitas produk terhadap keputusan pembelian melalui sistem online. Sebagaimana penelitian yang dilakukan Anthasari dan Widiastuti (2016), dengan hasil penelitian bahwa 
kepercayaan, keamanan dan persepsi risiko berpengaruh signifikan terhadap produk keputusan pembelian sophie martin melalui sistem online di Surakarta. Adapun penelitian oleh Sfenrianto, Gunawan, Kelly, dan E.Tarigan (2015), mengkonfirmasi temuan hasil penelitian bahwa kualitas web, keamanan dan kepercayaan adalah faktor penting yang mempengaruhi keputusan pembelian. Selanjutnya penelitian oleh Nawangsari (2014), hasilnya menunjukan terdapat pengaruh yang tidak searah atau bernilai negatif pada kepercayaan, terdapat pengaruh yang positif dan signifikan kualitas produk terhadap keputusan pembelian, dan terdapat pengaruh yang positif dan signifikan keamanan terhadap keputusan pembelian.

Shopee berdiri sejak tahun 2015, shopee merupakan perusahaan yang bergerak dibidang marketplace. Shopee sendiri dikelola oleh Garena Group yang sekarang berubah nama menjadi SEA Group. Shopee pertama kali dimulai sebagai pasar C2C (Pelanggan untuk Pelanggan) tetapi kemudian beralih model hibrid C2C (Pelanggan untuk Pelanggan) dan B2C (Bisnis untuk Pelanggan), hal itu berjalan semenjak diluncurkannya Shopee Mall yang merupakan platfrom toko daring milik shopee untuk distribusi brand ternama. Sarana jual beli ini juga menyediakan banyak produk mulai dari gadget, fashion, kosmetik, elektronik, otomotif. Hingga kini marketplace online shopee memiliki banyak pengguna setia yang berbelanja melalui akun ini.

Adapun fenomena yang ada dan dikutip dari merahputih.com bahwa kondisi pada shopee dalam hal kepercayaan masih terbilang kurang baik karena dapat dilihat dari adanya beberapa kekurangan seperti respon penjual yang terkadang cukup lama. Selanjutnya dalam hal keamanan lemahnya pelayanan yang diberikan situs shopee yang menjadikan kekhawatiran konsumen akan keamanan yang berhubungan dengan privasi konsumen, kekhawatiran menjadi korban penipuan online dan banyaknya persepsi risiko dibenak konsumen. Kemudian dalam hal kualitas produk beberapa gambar atau tampilan produk yang dianggap tidak sesuai dengan barang yang diiklankan. Semua itu menjadi faktor yang mempengaruhi konsumen dalam melakukan keputusan pembelian online.

\section{LANDASAN TEORI}

\section{Keputusan Pembelian}

Schiffman \& Kanuk (2007), mendefinisikan "keputusan sebagai pemilihan suatu tindakan dari dua atau lebih pilihan alternatif. Seorang konsumen yang hendak melakukan pilihan maka ia harus memiliki pilihan alternatif". Adapun menurut Swastha (2000), keputusan pembelian adalah "salah satu tahap dari keseluruhan proses mental dan kegiatan fisik lainnya yang terjadi dalam proses pembelian pada suatu periode dan waktu tertentu serta pemenuhan kebutuhan tertentu dengan kata lain serangkaian tahapan yang diambil oleh seorang konsumen". Selanjutnya Kotler \& Armstrong (2016),menyatakan keputusan pembelian merupakan bagian dari perilaku konsumen yaitu "studi tentang bagaimana individu, kelompok, dan organisasi memilih, membeli, menggunakan dan bagaimana barang, jasa, ide atau pengalaman untuk memuaskan kebutuhan dan keinginan mereka".

Adapun Keputusan Pembelian Online (Online Purchase) menurut Andrade (2000) adalah "proses seleksi yang mengkombinasikan pengetahuan untuk mengevaluasi dua atau lebih perilaku alternatif dan memilih salah satu diantaranya yang kuat hubungannya dengan karakter personal, vendor/service, website quality, sikap pada saat pembelian, maksud untuk membeli online dan pengambilan keputusan". Berdasarkan beberapa definisi diatas 
dapat dimaknai bahwa keputusan pembelian merupakan sebuah proses tindakan keputusan yang dilakukan konsumen untuk membeli suatu produk. Oleh karena itu, pengambilan keputusan pembelian konsumen merupakan suatu proses pemilihan salah satu dari beberapa preferens dan alternatif.

Keputusan untuk membeli suatu produk baik barang maupun jasa timbul karena adanya dorongan emosional dari dalam diri maupun pengaruh dari luar. Proses keputusan pembelian merupakan proses psikologis dasar yang memainkan peranan penting dalam memahami bagaimana konsumen benar-benar mambuat keputusan pembelian meraka. Proses keputusan pembelian model lima tahap menurut Kotler dan Amstrong (2016) adalah sebagai berikut: 1). Pengenalan kebutuhan yaitu proses pembelian dimulai ketika pembeli menyadari suatu masalah atau kebutuhan yang dipicu oleh rangsangan internal atau eksternal. 2). Pencarian informasi yang mana sumber informasi utama dimana konsumen dibagi mejadi yaitu Pribadi: keluarga, teman, tetangga, rekan. Komersial: Iklan dan situs web. Publik: Media massa, organisasi pemeringkat konsumen. 3). Evaluasi alternatif yang merupakan konsep dasar untuk membantu memahami proses evaluasi: konsumen berusaha memuaskan sebuah kebutuhan. selanjutnya, konsumen mencari manfaat tertentu dati solusi produk. Berikutnya konsumen melihat masing-masing produk sebagai sekelompok atribut dengan berbagai kemampuan untuk menghantarkan manfaat yang diperlukan untuk memuaskan kebutuhan ini. 4). Tahap evaluasi yaitu konsumen membentuk preferensi antar merek dalam kumpulan pilihan. Konsumen mungkin juga membentuk maksud untuk membeli merek yang paling disukai. Dalam melaksanaan maksud pembelian, konsumen dapat membentuk lima sub keputusan: merek, penyalur, kuantitas, waktu, dan metode pembayaran.

5). Perilaku pasca pembelian yaitu setelah melakukan pembelian konsumen mungkin mengalami konflik dikarenakan melihat fitur mengkhawatirkan tertentu atau mendengar hal-hal menyenangkan tentang merek lain dan waspada terhadap informasi yang mendukung keputusannya.

\section{Kepercayaan}

Menurut Kotler dan Keller (2016) berpendapat bahwa" kepercayaan konsumen adalah kepercayaan adalah kesediaan perusahaan untuk bergantung pada mitra bisnis. Itu tergantung pada sejumlah faktor interpersonal antar organisasi, seperti kompetensi yang dirasakan perusahaan, integritas, kejujuran,dan kebijakan". Menurut Andromeda (2015), "kepercayaan konsumen terhadap website online shopping terletak pada popularitas website online shopping itu sendiri, semakin bagus website, konsumen akan lebih yakin dan percaya terhadap reliabilitas website tersebut". McKnight (2015), menyatakan kepercayaan konsumen adalah sebagai berikut: "kepercayaan pelanggan sebagai harapan positif konsumen terhadap produsen atas kemampuannya menghasilkan produk yang memuaskan pelanggan". Dari pendapat para ahli tersebut, dapat dikatakan bahwa kepercayaan merupakan suatu keadaan yang terjadi ketika seseorang konsumen percaya atas integritas dan kejujuran website online tersebut.

Ada beberapa dimensi dan indikator untuk dapat mengetahui kepercayaan konsumen, menurut Kotler dan Keller (2016) ada empat indikator kepercayaan konsumen: 1). Benevolence (kesungguhan atau ketulusan) yaitu seberapa besar seseorang percaya kepada penjual untuk berperilaku baik kepada konsumen. 2). Ability (kemampuan) adalah sebuah penilaian terkini atas apa yang dapat dilakukan seseorang. Dalam hal ini bagaimana penjual mampu meyakinkan 
pembeli dan pemberikan jaminan kepuasan dan keamanan ketika bertransaksi. 3). Integrity (integritas) yaitu seberapa besar keyakinan seseorang terhadap kejujuran penjual untuk menjaga dan memenuhi kesepakatan yang telah dibuat kepada konsumen. 4). Willingness to depend adalah kesediaan konsumen untuk bergantung kepada penjual berupa penerimaan risiko atau konsekuensi negatif yang mungkin terjadi.

\section{Keamanan}

Masalah keamanan merupakan salah satu aspek penting dari sebuah sistem informasi. Keamanan transaksi online adalah bagaimana dapat mencegah penipuan (cheating) atau paling tidak mendeteksi adanya penipuan disebuah sistem yang berbasis informasi, dimana informasinya sendiri tidak memiliki arti fisik. Sangat pentingnya nilai sebuah informasi menyebabkan seringkali informasi yang diinginkan hanya boleh diakses oleh orang-orang tertentu. Jatuhnya informasi ke tangan pihak lain dapat menimbulkan kerugian bagi pemilik informasi. Untuk itu keamanan dari sistem informasi yang digunakan harus terjamin dalam batas yang dapat diterima. Park \& Kim (2006) medefinisikan keamanan atau security sebagai "kemampuan toko online dalam melakukan pengontrolan dan penjagaan keamanan atas transaksi data". Lebih lanjut Park dan Kim (2006) mengatakan bahwa jaminan keamanan berperan penting dalam pembentukan kepercayaan dengan mengurangi perhatian konsumen tentang penyalahgunaan data pribadi dan transaksi data yang mudah rusak. Ketika level jaminan keamanan dapat diterima dan bertemu dengan harapan konsumen, maka konsumen mungkin akan bersedia membuka informasi pribadinya dan akan membeli dengan perasaan aman.

Menurut Simons dalam Raharjo (2015), "keamanan adalah bagaimana kita dapat mencegah penipuan atau paling tidak, mendeteksi adanya penipuan disebuah sistem yang berbasis informasi, dimana informasinya sendiri tidak memiliki arti fisik" Arasu dan Viswanathan (2011), mendefinisikan "keamanan adalah inti dari sebagian besar transaksi internet. Keamanan merupakan faktor kunci yang menjadi perhatian orang menggunakan internet untuk membeli, karena sebagian transaksi dilakukan di internet". Menurut Wijaya dan Jasfar (2014) yang menganggap masalah keamanan (security) merupakan faktor yang berpengaruh pada niat pembelian online., dan memberikan pengaruh yang besar terhadap pembelian melalui online shopping.

Berdasarkan beberapa definisi diatas dapat dikatakan bahwa keamanan adalah sebuah upaya yang dilakukan untuk meminimalisir kerusakan yang terjadi pada sebuah sistem, keamanan juga dibuat untuk membentengi semua gangguan yang di buat secara sengaja maupun tidak sengaja. Keamanan berperan penting dalam pembentukan kepercayaan dengan mengurangi perhatian konsumen tentang penyalahgunaan data pribadi dan transaksi data yang mudah rusak

\section{Kualitas Produk}

Produk merupakan inti dari sebuah kegiatan pemasaran karena produk merupakan output atau hasil dari salah satu kegiatan atau aktivitas perusahaan yang dapat ditawarkan ke pasar sasaran untuk memenuhi kebutuhan dan keiinginan konsumen. Pada dasarnya dalam membeli suatu produk, seseorang konsumen tidak hanya membeli produk, akan tetapi konsumen juga membeli manfaat atau keunggulan yang dapat diperoleh dari produk yang dibelinya. Oleh karena itu, suatu produk harus memiliki keunggulan dari produk-produk yang lain, salah satunya dari segi kualitas produk yang ditawarkan. Kualitas produk merupakan salah satu kunci persaingan 
diantara pelaku usaha yang ditawarkan kepada konsumen.

Menurut Kotler dan Keller (2016), menyatakan bahwa "kualitas produk adalah kemampuan suatu barang untuk memberikan hasil atau kinerja yang sesuai bahkan melebihi dari apa yang diinginkan pelanggan". Kotler dan Armstrong (2015) mendefinisikan kualitas adalah" karakteristik dari suatu produk atau layanan yang bergantung pada kemampuannya untuk memenuhi kebutuhan pelanggan yang dinyatakan atau tersirat. Berdasarkan beberapa definisi diatas dapat dikatakan bahwa kualitas produk merupakan kemampuan suatu produk dalam memenuhi keinginan konsumen. Keinginan konsumen tersebut diantaranya daya tahan produk, keandalan produk, kemudahan pemakaian, serta atribut bernilai lainnya yang bebas dari kekurangan dan kerusakan.

Kualitas produk memiliki dimensi yang dapat digunakan untuk menganalisis karakteristik dari suatu produk. Tjiptono (2016), menyatakan kualitas produk memiliki delapan dimensi sebagai berikut: 1). Performance (kinerja), merupakan karakteristik operasi pokok dari produk inti (core product) yang dibeli. 2). Features (fitur atau ciri-ciri tambahan), yaitu karakteristik sekunder atau pelengkap. 3). Reliability (reliabilitas), yaitu kemungkinan kecil akan mengalami kerusakan atau gagal dipakai. 4). Confermance to Specifications (kesesuaian dengan spesifikasi), yaitu sejauh mana karakteristik desain dan operasi memenuhi standar-standar yang telah ditetapkan sebelumnya. 5). Durability (daya tahan), yaitu berkaitan dengan berapa lama produk tersebut dapat digunakan. 6). Serviceability, meliputi kecepatan, kompetensi, kenyamanan, kemudahan,direparasi, serta penanganan keluhan secara memuaskan. 7). Esthetics (estetika), yaitu daya tarik produk terhadap panca indera. 8). Perceived quality (kualitas yang dipersepsikan), yaitu citra dan reputasi produk serta tanggung jawab perusahaan terhadapnya.

Dari beberapa dimensi tersebut, dimensi yang memiliki relevansi dengan penelitian ini yaitu performance (kinerja), features (fitur), realibility (keandalan), conformance to spesification (kesesuaian dengan spesifikasi), durability (ketahanan), esthetics (estetika) dan perceived quality (kualitas yang dipersepsikan).

\section{METODE PENELITIAN}

\section{Rancangan Penelitian}

Penelitian ini merupakan studi kasus pada transaksi perdagangan melalui media elektronik (E-commerce),yang dirancang untuk menjelaskan pengaruh kepercayaan, keamanan, dan kualitas produk sebagai variabel independen terhadap keputusan pembelian sebagai variabel dependen, baik secara parsial maupun simultan melalui pengujian hipotesis.Data yang digunakan untuk penelitian ini merupakan data primer yang diperoleh melalui pengisian kuesioner yang disebarkan menggunakan instagram.

\section{Metode Pengumpulan Data}

Proses penelitian ini antara lain mengumpulkan data yang berupa data primer, yang diperoleh melalui pengisian kuesioner oleh followers instagram, dengan menggunakan Skala Likert. Skala Likert yang digunakan adalah sangat setuju dengan bobot 5, setuju dengan bobot 4 , netral dengan bobot 3 , tidak setuju dengan bobot 2 , dan sangat tidak setuju dengan bobot 1 .

Objek penelitian yang diteliti adalah online shopp dengan sistem transaksi $e$ commerce yang cukup terkenal di Indonesia, yaitu Shopee.co.id. Adapun jumlah populasi sebanyak 1200 orang yang merupakan followers instagram yang berbelanja berulangkali di online shopp Shopee. Teknik pengambilan sampel dilakukan dengan menggunakan simple 
random sampling yaitu memberikan peluang yang sama bagi setiap anggota populasi untuk dipilih menjadi sampel secara acak sederhana. Jumlah sampel yang diperoleh dengan menggunakan rumus Slovin adalah sebanyak 92 orang.

\section{Metode Analisis Data}

Untuk menganalisis pengaruh dari masing-masing variabel independen digunakan metode analisis regresi linear sederhana (simple linear regression), yaitu : $Y=a+\beta_{i} X_{i}$

Untuk menganalisis pengaruh variabel independen secara bersama-sama digunakan metode regresi linear berganda (multiple linear regression), yaitu : $\mathrm{Y}=\mathrm{a}$ $+b_{1} X_{1}+b_{2} X_{2}+b_{3} X_{3}$

di mana;

$$
\begin{aligned}
& Y=\text { Keputusan Pembelian } \\
& X_{i}=\left(i=X_{1}, X_{2}, X_{3}\right)
\end{aligned}
$$

$\mathrm{X} 1=$ Kepercayaan

$\mathrm{X} 2$ = Keamanan

X3 = Kualitas Produk

$\alpha=$ Konstanta

$\beta_{i}=$ Koefisien regresi $(i=1,2,3)$

dari masing-masing variabel independen

\section{HASIL DAN PEMBAHASAN}

\section{Hasil Penelitian}

\section{Uji Validitas dan Reliabilitas}

Hasil pengujian terhadap 26 butir pernyataan untuk variabel penelitian yang terdiri dari kepercayaan, keamanan, kualitas produk, dan keputusan pembelian dinyatakan valid dan reliabel, artinya responden telah memahami dan responden konsisten pada butir pernyataan yang diajukan.

\section{Hasil Uji Hipotesis}

Tabel 1 : Pengaruh Parsial Kepercayaan, Keamanan, dan Kualitas Produk Terhadap Keputusan Pembelian

\begin{tabular}{lccccl}
\hline \multicolumn{1}{c}{ Variabel } & Konstanta & Koef.Reg & $\mathbf{R}^{\mathbf{2}}$ & Nilai t & Nilai p \\
\hline Kepercayaan & 21.946 & 0.723 & 0.151 & 4.007 & $0.000^{*}$ \\
Keamanan & 11.038 & 1.073 & 0.580 & 11.148 & $0.000^{*}$ \\
Kualitas Produk & 5.556 & 1.554 & 0.582 & 11.191 & $0.000^{*}$ \\
\hline
\end{tabular}

Tabel : 1 menunjukkan bahwa hipotesis 1 hingga hipotesis 3 secara parsial dalam persamaan regresi linear sederhana, seluruh variabel independen berpengaruh positif dan signifikan (nilai $p$ atau nilai probabilitas lebih kecil dari 0,05 atau $p$-value $<0,05)$, sehingga dapat dinyatakan bahwa hipotesis 1 hingga hipotesis 3 dapat diterima, yaitu masingmasing variabel independen secara parsial berpengaruh terhadap varibel dependen secara positif dan signifikan.

Berdasarkan hipotesis 1, Menunjukkan koefisien determinasi $\left(\mathrm{R}^{2}\right)$ untuk kepercayaan sebesar 0,151 atau 15,1\%. Hal ini dimaknai bahwa kepercayaan memberikan kontribusi kepada keputusan pembelian sebesar $15,1 \%$, sedangkan sisanya sebesar $84,9 \%$ disumbangkan oleh faktor lain. Adapun nilai $t_{\text {hitung }}$ sebesar 4,007 dan pvalue sebesar 0,000 sehingga $p$ value $<0,05$. Dengan demikian hipotesis 1 diterima dan teruji.

Berdasarkan hipotesis 2, Menunjukkan koefisien determinasi $\left(\mathrm{R}^{2}\right)$ untuk keamanan sebesar 0,580 atau 58\%. Hal ini dimaknai bahwa keamanan memberikan kontribusi kepada keputusan pembelian sebesar 58\%, sedangkan sisanya sebesar $42 \%$ disumbangkan faktor lain. Adapun nilai $t_{\text {hitung }}$ sebesar 11.148 dan $p$ value sebesar 0,000 sehingga $p$ 
value $<0,05$. Dengan demikian hipotesis 2 diterima dan teruji.

Berdasarkan hipotesis 3, menunjukkan koefisien determinasi $\left(\mathrm{R}^{2}\right)$ untuk kualitas produk sebesar 0,582 atau $58,2 \%$. Hal ini dimaknai bahwa kualitas produk memberikan kontribusi kepada keputusan pembelian sebesar 58,2\%, sedangkan sisanya sebesar $41,8 \%$ disumbangkan faktor lain. Adapun nilai

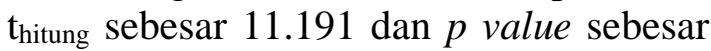
0.000 sehingga $p$ value $<005$. Dengan demikian hipotesis 3 diterima dan teruji.

Tabel 2 : Pengaruh Simultan Kepercayaan, Keamanan, dan Kualitas Produk Terhadap Keputusan Pembelian

\begin{tabular}{lccccc}
\hline \multicolumn{1}{c}{ Variabel } & Konstanta & Koef.Reg & $\mathbf{R}^{2}$ & Nilai F & Nilai p \\
\hline Kepercayaan & & -0.115 & & & \\
Keamanan & 4.111 & 0.625 & 0.676 & 64.410 & $0.000^{*}$ \\
Kualitas Produk & & 0.990 & & & \\
\hline
\end{tabular}

Berdasarkan hipotesis 4, menunjukkan nilai $F_{\text {hitung }}$ sebesar 64.410 dan $p$ value sebesar 0.000 sehingga $p$ value < 005. Adapun koefisien determinasi $\left(\mathrm{R}^{2}\right)$ untuk kepercayaan, keamanan, dan kualitas produk secara bersama-sama sebesar 0,676 atau 67,6\%, dan dimaknai memberikan kontribusi kepada keputusan pembelian secara online sebesar $67,6 \%$, sedangkan sisanya sebesar $32,4 \%$ disumbangkan faktor lain. Dengan demikian hipotesis 4 diterima dan teruji.

Tabel 2 menunjukkan bahwa koefisien regresi untuk kepercayaan bernilai negatif sebesar -0.115 . Hal ini dapat dimaknai semakin berkurangnya kepercayaan, maka akan semakin turun keputusan untuk melakukan pembelian atau transaksi pembelian secara online dengan Shoppe. Adapun koefisien regresi untuk keamanan sebesar 0,625 dapat dimaknai jika ada peningkatan keamanan maka akan mempengaruhi peningkatan pada keputusan pembelian sebesar 0,625 dengan asumsi jika kepercayaan dan kualitas produk nilainya tetap. Koefisien bernilai positif ini memberi arti semakin tinggi keamanan bertransaksi dengan Shoppe maka akan semakin meningkat untuk melakukan keputusan pembelian secara online. Sedangkan koefisien regresi untuk kualitas produk sebesar 0.990 dapat dimaknai jika ada peningkatan kualitas produk maka akan mempengaruhi peningkatan pada keputusan pembelian sebesar 0.990 dengan asumsi jika kepercayaan dan keamanan nilainya tetap. Koefisien bernilai positif ini memberi arti semakin tinggi kualitas produk yang dijual Shoppe maka semakin meningkat untuk melakukan keputusan pembelian secara online.

\section{Pembahasan}

Kepercayaan memberikan pengaruh terhadap keputusan pembelian. Hal ini dikarenakan konsumen atau pembeli percaya terhadap produk yang dijual shopee, konsumen percaya berbelanja dishopee dengan adanya syarat dan ketentuan yang jelas dan shopee dapat mereferensikan produk terbaik dari berbagai toko. Hubungan interpersonal yang baik antara pembeli dengan pihak Shoppe merupakan faktor yang menambah kepercayaan untuk melakukan tarnsaksi dengan Shoppe. Hasil penelitian ini sejalan dengan penelitian terdahulu yang dilakukan oleh Yuniarti (2016), dengan hasil penelitian secara parsial kepercayaan memiliki pengaruh positif dan signifikan terhadap keputusan pembelian secara online.

Keamanan memberikan pengaruh terhadap keputusan pembelian. Hal ini dikarenakan konsumen dapat melihat 
informasi pesanan setelah melakukan pembayaran dan bukti transaksi shopee yang dapat digunakan sebagai garansi. Dalam hal ini konsumen merespon positif dan konsumen juga akan lebih merasa aman untuk berbelanja di shopee.Hasil penelitian ini sejalan dengan penelitian terdahulu yang dilakukan oleh Wijaya dan Jasfar (2015), dengan hasil penelitian keamanan memiliki pengaruh positif dan signifikan terhadap keputusan pembelian melalui online.

Kualitas produk memberikan pengaruh yang positif dan signifikan terhadap keputusan pembelian. Hal ini dikarenakan shopee memberikan beragam produk untuk memenuhi kebutuhan konsumen dan shopee menawarkan beragam produk dengan variasi harga yang sesuai. Hasil penelitian ini sejalan dengan penelitian terdahulu yang dilakukan oleh Hendra \& Lusiah (2017), dengan hasil penelitian Kualitas produk memiliki pengaruh signifikan terhadap keputusan pembelian produk.

Secara simultan terdapat pengaruh keamanan dan kualitas produk terhadap keputusan pembelian. Hasil penelitian menunjukkan secara umum konsumen mengapresiasi terhadap keamanan dan kualitas produk, dan mendapatkan tanggapan yang positif, dibandingkan dengan kepercayaan mempunyai pengaruh yang tidak searah atau negatif. Hal ini menunjukkan konsumen memiliki rasa kurang percaya untuk melakukan pembelian berulang yang disebabkan rasa ragu terhadap jaminan originalitas produk yang dijual Shopee. Hasil penelitian ini mempunyai hasil yang sama dengan penelitian terdahulu yang dilakukan oleh Nawangsari (2016), Hasil penelitian menyatakan kualitas produk dan keamanan memiliki pengaruh yang positif dan signifikan terhadap keputusan pembelian. Sedangkan kepercayaan memiliki pengaruh yang tidak searah atau bernilai negatif.

\section{KESIMPULAN DAN SARAN}

\section{Kesimpulan}

Hasil penelitian memberikan kesimpulan bahwa kepercayaan, keamanan dan kualitas produk mendorong konsumen untuk memutuskan melakukan pembelian secara online. Kualitas produk selanjutnya diikuti rasa aman (keamanan) yang paling berkontribusi mendorong untuk dilakukan keputusan melakukan pembelian baik secara sendiri-sendiri. secara bersama-sama kualitas produk dan keamanan secara positif berkontribusi mendorong dilakukannya keputusan pembelian, hal tersebut dikarenakan konsumen dapat melihat informasi pesanan setelah melakaukan pembayaran, bukti transaksi dapat digunakan sebagai garansi, produk yang dijual Shoppe tidak mudah rusak, dan terjamin originalitasnya. Secara bersama-sama, kepercayaan justru memberikan tanggapan yang negatif, artinya tidak menjadi faktor yang menambah dorongan untuk memutuskan melakukan pembelian,yaitu belum tentu melakukan pembelian yang berulang.

\section{Saran}

Shoppe harus dapat meningkatkan kepercayaan konsumen dengan memberikan suatu jaminan bahwa tokotoko yang produknya di jual melaului Shoppe merupakan produk unggulan, meningkatkan dan memberikan kemudahan berkomunikasi konsumen dengan pihak Shoppe, dan persyaratan transaksi yang tidak multi tafsir di mata konsumen. Perlu dipertimbangkan untuk dilakukan penelitian berikutnya dengan menggunakan faktor harga, ekuitas merek, loyalitas merek, citra merek, dan citra perusahaan.

\section{DAFTAR PUSTAKA}


Andrade, E. 2000. "Identifying discriminatingvariables of online and offline buyers: A perceivedrisk approach," Proceedings ofthe 6 th Americas Conference on Information Systems, pp. 13861392.Antarwiyati, P., Agus, L.N., dan Hadri, K., 2010, "Determinan Electronic Loyalty (eLoyalty) Pada Website", Jurnal Akuntansi \& Auditing Indonesia, 14 (1)

Andromeda, Kevin.2015.“Analisis Pengaruh Kepercayaan, Kemudahan, dan Keragaman Produk Pakaian Via Online Terhadap Keputusan Pembelian Secara Online (Studi kasus pada mahasiswa belanja online pada FEB Universitas Muhammadiyah Surakarta)"

Anthasari dan Widiastuti. 2016. Pengaruh Faktor Kepercayaan, Keamanan Dan Persepsi Pada Resiko Terhadap Keputusan Pembelian Produk Shopie Martin Melalui Sistem Online DiSurakarta. Jurnal Penelitian dan Kajian Ilmiah Fakultas Ekonomi. Vol.14 No.3.

Armstrong, Kotler 2015, "Marketing an Introducing Prentice Hall twelfth edition", England : Pearson Education, Inc

Ghozali, Imam. 2016. Aplikasi Analisis Multivariate dengan Program IBM SPSS. Yogyakarta: Universitas Diponegoro

Hardiyanti, Nia (2012). Analisis Pengaruh Insider Ownership, Leverage, Profitabilitas, Firm Size dan Dividen Payout Ratio terhadap Nilai Perusahaan. Skripsi. Universitas Diponegoro. Semarang

Hendra and Lusiah, 2017. Impact of Brand Image, Product Quality and SelfEfficacy on Purchase Decisions on Private Label Rights Products. An Empirical Study. Expert Journal of Business and Management.
Jony Wong. 2010. Internet Marketing for Beginners. PT Elex Media Komputindo. Jakarta.

Kotler, Philip. \& Gary Armstrong. (2016). Principle Of Marketing, 15th edition. New Jersey: Pearson Prentice Hall.

Kotler, Philip and Kevin Lane Keller, 2016. Marketing Managemen, 15th Edition, Pearson Education,Inc.

Kotler, Philip and Kevin Lane Keller, (2016), Marketing Management, (16thEdition), New Jersey: Prentice Hall Published.

Lita Limpo dan Meryana. 2017. "Effect of Trust and Easy on Decision Online Purchase toward Special Fashion Product". ISSN: 2319-7064

McKnight, D.H., Choudhury, V., Kacmar, C. (2015). Developing and validating trust measures for $e$ commerce: an integrative typology. Inf. Syst. Res. 13(3), 334-359.

Nawangsari. $2017 . \quad$ Pengaruh Kepercayaan, Kualitas Produk dan Keamanan Terhadap Keputusan Pembelian (Pada Tokopedia.com). Jurnal Manajemen Bisnis Indonesia. Vol.4 No.3.

Park, Chung-Hoon., and Young-Gul Kim., 2006, The Effect of Information Satisfaction and Relational Benefit on Consumers Online Site Commitmennts. Journal of Electronic Commerce in Organizations, 4 (1), p. 70-90.

Park, E.J., Kim, E.Y. 2006. A structural model of fashion-oriented impulse buying behavior, Journal of Fashion Marketing and Management, Vol. 10 No. 4, pp. 433-446

Priyatno, Duwi. 2012. Cara Kilat Belajar Analisis Data dengan SPSS 20. Edisi Kesatu. Yogyakarta: ANDI

Priyatno, Duwi. 2014. SPSS 22 Pengolah Data Terpraktis. Andi. Yogyakarta. 
Priyanto, Jauhari. 2014. Pemrograman Web. Bandung: Informatika Bandung.

Raharjo,Budi., Heryanto,Imam \& R.K,Enjang. 2015. Pemrograman WEB (HTML, PHP, \& MYSQL). Bandung: Modula.

Raman, Arasu, dan Viswanathan, A. 2011. Web Services and e-Shopping Decisions: A Study on Malaysian eConsumer. IJCA Special Issueon:Wireless Information Networks \& Business Information System, hal.54-60.

Sfenrianto, Gunawan, Kelly, and Tarigan, E. 2015. The Use of Quality, Security and Trust Factors to Improve The Online Purchase Decision, Journal of Theoretical and Applied Information Technology, Vol. 96 No.5

Schiffman, Leon G., \& Leslie Lazar Kanuk. 2007. Perilaku Konsumen. Jakarta: Indeks.

Sugiyono. 2017. Metode Penelitian Kuantitatif, Kualitatif, dan $R \& D$. Bandung: Alfabeta.

Suharyadi dan Purwanto. 2004. Metodologi Penelitian. Jakarta: Gramedia Pustaka Utama.

Sujarweni, V. Wiratna. 2015. Statistik untuk Bisnis dan Ekonomi. Yogyakarta: Pustaka Baru Press.
Sunyoto, Danang. 2016. Metodologi Penelitian Akuntansi. Bandung: PT Refika Aditama

Tjiptono, Fandy dan Chandra, Gregorius. 2016. Service Quality and Satisfaction (edisi ketiga). Yogyakarta :CVAndi Offset

Triana. 2015. Pengaruh harga, Kepercayaan dan Kualitas Pelayanan Terhadap Keputusan Pembelian Pada Perdagangan Ecommerce (Studi Kasus Pada Miulan Hijab Semarang). Skripsi. Semarang: Universitas Islam Negeri Walisongo.

Wijaya, Megawati dan Farida Jasfar. 2015. "Pengaruh Rancangan Situs, Harga, Kepercayaan dan Keamanan Terhadap Pembelian Produk Fashion Melalui Online Shoping".Jurnal Manajemen dan Pemasaran Jasa.Volume 7 Nomor 2.halaman 31-62.

Yenny Yuniarti. 2016. Pengaruh Kualitas Produk, Harga, Dan Kepercayaan Terhadap Keputusan Pembelian Produk Fashion Secara Online. Vol.18 No. 1 Hal 27-37 Januari Juni 2016ISSN: 0852-8349.

https://merahputih.com/post/read/kelebih an-dan-kekurangan-situs-situsbelanja-online 